\title{
Efektivitas Pemberian Metilprednisolon terhadap Pembentukan Seroma Pascaoperasi Mastektomi Modifikasi Radikal
}

\author{
Jonny Setiawan, ${ }^{1}$ Maman Abdurahman, ${ }^{2}$ Kiki A. Rizki ${ }^{2}$ \\ ${ }^{1}$ Departemen Ilmu Bedah Fakultas Kedokteran Universitas Atmajaya Jakarta, ${ }^{2}$ Departemen Ilmu Bedah \\ Fakultas Kedokteran Universitas Padjadjaran/Rumah Sakit Dr. Hasan Sadikin Bandung
}

\begin{abstract}
Abstrak
Seroma adalah pengumpulan cairan serous di subkutis dan merupakan komplikasi pascaoperasi kanker payudara yang paling sering dijumpai. Insidensinya mencapai lebih dari $60 \%$. Walaupun tidak mengancam jiwa, namun dapat menimbulkan morbiditas yang serius. Berbagai penelitian dilakukan untuk menentukan faktor risiko untuk mencegah timbulnya seroma. Saat ini, seroma terjadi karena proses inflamasi pascaoperasi. Teori inilah yang mendasari peranan antiinflamasi terhadap pembentukan seroma. Diketahui obat golongan glukokortikoid, memiliki peranan menghambat respons inflamasi. Tujuan penelitian ini untuk menilai efek profilaksis pemberian metilprednisolon perioperatif mastektomi terhadap pembentukan seroma. Penelitian ini merupakan uji klinis secara acak tersamar ganda terhadap 2 kelompok, yaitu antara kelompok karsinoma payudara stadium lokal lanjut yang diberikan metilprednisolon perioperatif mastektomi sebagai kelompok perlakuan dan kontrol. Penelitian ini dilakukan di Rumah Sakit Dr. Hasan Sadikin Bandung, periode April-Juli 2013. Subjek penelitian meliputi 30 wanita yang memenuhi kriteria inklusi dan dibagi menjadi dua kelompok, 15 pasien diberikan metilprednisolon dan 15 pasien sebagai kontrol. Penelitian ini menggunakan uji-t tidak berpasangan dan Mann Whitney. Didapatkan perbedaan rata-rata volume drainase hari ke-1, pada kelompok metilprednisolon sebanyak $104,7 \mathrm{~mL}$ dan pada kontrol sebanyak $158 \mathrm{~mL}$, namun secara statistik tidak bermakna $(\mathrm{p}=0,053)$. Demikian pula dengan hari-hari selanjutnya dan total seroma, tidak didapatkan perbedaan yang bermakna. Simpulan, pemberian metilprednisolon tidak efektif menurunkan volume drainase seroma pascaoperasi mastektomi. [MKB. 2014;46(2):88-93]
\end{abstract}

Kata kunci: Mastektomi, metilprednisolon, seroma

\section{Effectiveness of Methylprednisolone on Post-Operative Seroma Formation Following Radical Modified Mastectomy}

\begin{abstract}
Seroma is a collection of serous fluid in the subcutaneous and is the most common complication of breast cancer surgery. The incidence is more than $60 \%$. Although it is not life-threatening but it can cause serious morbidity. Various studies were conducted to determine the risk factors to prevent seroma formation. Currently, seroma occurrs due to postoperative inflammatory processes. This theory underlies the antiinflammatory role for seroma formation. Glucocorticoid drugs is known as playing a role in inhibiting the inflammatory response. The purpose of this study was to assess the prophylactic effect of perioperative administration of methylprednisolone on seroma formation. This study was a double-blind randomized control trial of 2 groups, i.e. a group of locally advanced breast carcinoma which were given methylprednisolone perioperatively as a treatment group and a control group. The research was conducted in Dr. Hasan Sadikin General Hospital Bandung from April to July 2013. Thirty women who met the inclusion criteria were included as subjects who were then divided into two groups: 15 women received methylprednisolone and 15 women serve as controls. This study used independent $t$ and Mann-Whitney tests. There was a difference in the mean volume of drainage on day 1 between the methylprednisolone and control group as much as $104.7 \mathrm{~mL}$ and $158 \mathrm{~mL}$, respectively, but not statistically significant $(\mathrm{p}=0.053)$. The same situation was also seen for the following days and total seroma, which was no significant difference was found. In conclusion, the use of methylprednisolone is not effective for reducing postoperative seroma drainage volume after mastectomy. [MKB. 2014;46(2):88-93]
\end{abstract}

Key words: Mastectomy, methylprednisolone, seroma

Korespondensi: Jonny Setiawan, dr., Departemen Ilmu Bedah Fakultas Kedokteran Universitas Atmajaya Jalan Pluit Raya 2, Jakarta Utara 14440, mobile,08161107290,e-mail jonnysetiawan@hotmail.com 


\section{Pendahuluan}

Seroma merupakan komplikasi pascaoperasi mastektomi pada kanker payudara yang paling banyak dijumpai dengan insidensi bervariasi 2,5-51\%. Hasil penelitian Hashemi dkk. ${ }^{1}$ di Iran menunjukkan insidensi sebesar 35\%, sedangkan di Polandia berdasarkan laporan Stanczyk dkk. ${ }^{2}$ pembentukan seroma terjadi hingga $50 \%$ setelah mastektomi. Karakaya dkk. ${ }^{3}$ menyatakan bahwa seroma merupakan komplikasi yang paling bermakna dan sering terjadi setelah tindakan mastektomi, dan menurut penelitian ini terjadi $31 \%$. Penelitian yang dilakukan oleh Junior ${ }^{4}$ di Divisi Bedah Onkologi Rumah Sakit Dr. Hasan Sadikin (RSHS) Bandung, data insidensi seroma pascatindakan operasi modifikasi mastektomi radikal adalah sebesar $62,5 \%$.

Seroma bukan merupakan komplikasi yang bersifat mengancam jiwa, namun keadaan ini mampu menimbulkan morbiditas yang cukup serius, karena keadaan ini berhubungan dengan penyulit lain seperti nekrosis flap kulit, rasa nyeri, infeksi, keterlambatan penyembuhan luka, luka operasi yang terbuka kembali, predisposisi terjadi sepsis, dan limfedema. Selain itu pengumpulan cairan yang berlebihan akan meregangkan kulit sehingga menjadi bergelambir dan menyebabkan ketidaknyamanan bagi pasien. Penyulit tersebut dapat memperpanjang hari perawatan dan juga memperlambat pemberian terapi adjuvan. ${ }^{1,5}$ Seroma biasanya hilang beberapa minggu setelah operasi, namun terdapat juga seroma yang baru hilang setelah beberapa bulan. Bahkan pernah dilaporkan kasus seroma yang bertahan sampai satu tahun pascaoperasi, sehingga terbentuk seroma fibrous terkapsulasi yang memerlukan suatu tindakan reseksi bedah setelah tindakan konservatif yang dilakukan gagal. ${ }^{2}$

Berdasarkan metaanalisis yang dilakukan oleh Kuroi dkk., ${ }^{6}$ banyak faktor yang memengaruhi kejadian seroma pascaoperasi kanker payudara. Faktor-faktor yang cukup signifikan yaitu berat badan yang berlebih, mastektomi radikal (bila dibandingkan mastektomi simpel), dan jumlah drainase yang banyak dalam 3 hari pertama.

Trauma pada tindakan operasi menimbulkan suatu trauma yang akan merangsang mediator inflamasi untuk menimbulkan proses inflamasi yang merupakan bagian dari proses penyembuhan luka. Berdasarkan faktor risiko tersebut, besarnya trauma dan radikalitas akan merangsang proses inflamasi yang lebih besar. Pada penelitian yang dilakikan oleh Soomro dkk. ${ }^{7}$ risiko seroma lebih besar pada operasi mastektomi modifikasi radikal yaitu sebesar $17,5 \%$, sedangkan pada operasi breast conserving surgery (BCT) tidak dijumpai kasus seroma. Keadaan ini juga didukung dengan hasil penelitian retrospektif oleh Setiawan dan Abdurahman $^{8}$ di divisi Bedah Onkologi Rumah Sakit Dr. Hasan Sadikin Bandung, yaitu operasi mastektomi radikal dapat meningkatkan insidensi seroma. Mediator inflamasi yang dilepaskan akan diikuti dengan peningkatan permeabilitas kapiler di daerah sekitar luka operasi. Kondisi ini akan menyebabkan ekstravasasi cairan yang kemudian akan membentuk seroma.

Kadar imunoglobin G ( $\mathrm{IgG})$, sel leukosit, dan granulosit lebih tinggi pada pasien seroma. Mediator inflamasi seperti proteinase, proteinase inhibitor, dan juga sitokin ditemukan dalam cairan seroma. Penelitian oleh Szecsi dkk. ${ }^{9}$ menunjukkan bahwa cairan seroma adalah suatu eksudat, yang dibuktikan dengan ditemukan komponen IL-6 dan IL-8 yang tinggi dalam cairan seroma. Hal ini memperlihatkan bahwa pembentukan seroma terjadi akibat reaksi akut proses inflamasi selama fase pertama proses penyembuhan luka.

Dengan dasar proses inflamasi tersebut, maka kondisi yang dapat menghambat atau mengurangi beratnya proses inflamasi tersebut, akan mampu mengurangi terjadinya seroma. Pada penelitian Sortino dan Cicciu, ${ }^{10}$ terjadi penurunan edema pascaoperasi di daerah rongga mulut sesudah kortikosteroid. Penelitian oleh Taghizadeh dkk. ${ }^{11}$ menyatakan bahwa pemberian glukokortikoid intermediate dapat menurunkan jumlah seroma secara signifikan, pada operasi flap latisimus dorsi. Keadaan ini juga didukung oleh penelitian Tahmasebi dkk. ${ }^{12}$ yang memperlihatkan bahwa tidak terdapat seroma pascaoperasi mastektomi, sesudah pemberian glukokortikoid intermediate preoperatif. Berbeda dengan penelitian Okholm dan Axelsson ${ }^{13}$ dinyatakan bahwa pemberian metilprednisolon $125 \mathrm{mg}$ preoperasi mastektomi, tidak menurunkan jumlah drainase seroma secara signifikan.

Penelitian ini bertujuan untuk menilai efek profilaksis metilprednisolon yang diberikan pada perioperatif mastektomi terhadap pembentukan seroma.

\section{Metode}

Penelitian ini merupakan suatu uji klinis acak tersamar ganda pada 2 (dua) kelompok, yaitu karsinoma payudara stadium lokal lanjut yang mendapat terapi metilprednisolon perioperatif mastektomi modifikasi radikal sebagai perlakuan, sedangkan sebagai kontrol yang tidak mendapat metilprednisolon untuk mengetahui perbedaan volume rata-rata drainase seroma.

Subjek penelitian ini adalah pasien wanita dengan diagnosis karsinoma payudara stadium lokal lanjut dan dilakukan operasi mastektomi 
modifikasi radikal di Rumah Sakit Dr. Hasan Sadikin (RSHS) Bandung. Kriteria eksklusinya yaitu penyakit komorbid hipertensi dan diabetes melitus. Ukuran sampel ditentukan menggunakan formula uji hipotesis dua rata-rata, sehingga besar sampel minimal untuk tiap kelompok 10 subjek.

Karsinoma payudara diagnosisnya ditegakkan berdasarkan atas anamnesis, pemeriksaan klinis, dan hasil biopsi insisi. Pemeriksaan penunjang dilakukan untuk dapat menentukan staging (foto toraks, ultrasonografi hati, dan sidik tulang). Jaringan tumor hasil biopsi insisi diperiksakan histopatologis di Departemen Patologi Anatomi Fakultas Kedokteran Universitas Padjadjaran/ RSHS Bandung dengan pewarnaan hematoksilin eosin (HE) untuk mengetahui jenis histopatologi tumor tersebut. Pasien karsinoma payudara yang termasuk stadium lokal lanjut yang dirawat dan dijadwalkan untuk tindakan operasi mastektomi modifikasi radikal diberikan penjelasan untuk diikutsertakan dalam penelitian. Pasien yang setuju ikut serta dalam penelitian, dibagi menjadi 2 kelompok perlakuan secara tersamar ganda dengan mempergunakan kode label obat yang sudah diacak dengan mempergunakan komputer tanpa diketahui oleh peneliti dan pasien. Kunci kode label yang sudah diacak dipegang oleh pembimbing penelitian. Pemberian obat serta observasi volume drainase seroma dilaksanakan oleh residen stase Bedah Onkologi yang bertugas di ruangan.

Setelah semua data terkumpul, kemudian dilaporkan ke pembimbing dan kunci kode label obat dibuka. Data yang diperoleh, diolah secara komputerisasi untuk mengubah data menjadi informasi. Sebelum dilakukan analisis bivariabel dilakukan terlebih dahulu uji normalitas data numerik yang meliputi usia, indeks massa tubuh, volume harian, dan total volume drainase pada kelompok terhadap pasien karsinoma payudara yang diberi terapi metilprednisolon perioperatif mastektomi modifikasi radikal dan kelompok kontrol yang memakai larutan $\mathrm{NaCl}$ fisiologis, dengan memakai Tes Shapiro Wilk untuk besar sampel sebanyak $<50$ orang. Data berdistribusi normal bila $\mathrm{p}>0,05$.

Sesudah dilaksanakan uji normalitas data, kemudian dilakukan analisis bivariabel untuk membandingkan volume drainase seroma ratarata antara kelompok pasien karsinoma payudara yang diberi terapi metilprednisolon perioperatif mastektomi modifikasi radikal dan kelompok kontrol, dengan mempergunakan uji parametrik yaitu uji-t tidak berpasangan, bila data volume drainase seroma rata-rata berdistribusi normal dan digunakan uji nonparametrik Mann Whitney bila data volume drainase seroma rata-rata tidak berdistribusi normal. Analisis data menggunakan program statistical product and service solutions (SPSS) versi 19 pada derajat kepercayaan 95\% dengan $\mathrm{p} \leq 0,05$.

Penelitian ini dilaksanakan April-Juli 2013. di Divisi Bedah Onkologi Kepala dan Leher, Departemen Ilmu Bedah Fakultas Kedokteran Universitas Padjadjaran/RSHS Bandung.

\section{Hasil}

Pada penelitian ini diikutsertakan 15 pasien untuk setiap kelompok dan berdasarkan hasil yang diperoleh dilakukan perbandingan karakteristik

Tabel 1 Perbandingan Karakteristik Subjek Penelitian

\begin{tabular}{|c|c|c|c|c|}
\hline \multicolumn{5}{|c|}{ Distribusi } \\
\hline \multicolumn{2}{|l|}{ Variabel } & Kontrol Plasebo (NaCl) & Metilprednisolon & $\left.\mathbf{p}^{*}\right)$ \\
\hline \multicolumn{5}{|l|}{ Usia } \\
\hline \multicolumn{2}{|l|}{ Rata-rata (SB) } & $46,27(6,76)$ & $50,27(9,65)$ & 0,199 \\
\hline \multicolumn{2}{|l|}{ Median (rentang) } & $46(37-59)$ & $52(30-63)$ & \\
\hline \multirow[t]{2}{*}{$95 \%$ IK } & Atas & 50,01 & 55,61 & \\
\hline & Bawah & 42,52 & 44,92 & \\
\hline \multicolumn{5}{|l|}{ IMT } \\
\hline \multicolumn{2}{|l|}{ Rata-rata (SB) } & $24,05(1,74)$ & $24,15(1,88)$ & \\
\hline \multicolumn{2}{|l|}{ Median (rentang) } & $24,14(19,43-26,56)$ & $24,03(20,69-26,67)$ & 0,889 \\
\hline \multirow[t]{2}{*}{$95 \%$ IK } & Atas & 25,02 & 25,19 & \\
\hline & Bawah & 23,09 & 23,1 & \\
\hline
\end{tabular}

Keterangan: *uji-t tidak berpasangan, IMT: indeks massa tubuh 
subjek penelitian berdasarkan usia dan indeks massa tubuh(IMT) padake-2 kelompok penelitian. Nilai $\mathrm{p}=0,199$ untuk distribusi berdasarkan usia dan $p=0,889$ untuk distribusi berdasarkan indeks massa tubuh (IMT) untuk pasien karsinoma payudara yang diberikan terapi metilprednisolon perioperatif dan kelompok kontrol (Tabel 1). Nilai probabilitas tersebut lebih besar daripada nilai alpha $(\mathrm{p}>0,05)$. Dengan demikian, dapat disimpulkan bahwa kelompok data berdistribusi normal. Oleh karena distribusi normal, dianggap bahwa perbedaan usia dan nilai IMT pada kedua kelompok penelitian tidak berbeda, sehingga tidak memengaruhi hasil penelitian.

Dilakukan kembali uji normalitas dengan menggunakan Uji Shapiro Wilk terhadap volume drainase seroma antara kedua kelompok pada hari ke-1, ke-2, ke-3, ke-4, ke-5 dan total akumulasi drainase selama 5 hari. Hasil uji normalitas data volume drainase seroma pada hari ke-1, hari ke-2 dan total drainase adalah $p>0,05$, sedangkan uji normalitas data volume drainase seroma pada hari ke-3, hari ke-4, dan hari ke-5 adalah $\mathrm{p}<0,05$ (Tabel 2). Berdasarkan atas hasil analisis tersebut, maka untuk mengetahui perbedaan volume drainase seroma rata-rata antara dua kelompok pada hari ke-1, ke-2, dan total drainase dipergunakan uji-t tidak berpasangan, sedangkan untuk mengetahui perbedaan volume drainase dari seroma rata-rata antara kedua kelompok pada hari ke-3, ke-4, dan ke-5 digunakan Uji Mann Whitney.

Volume drainase seroma rata-rata kelompok yang diberikan obat metilprednisolon lebih rendah dibandingkan dengan kelompok kontrol (Tabel
3). Nilai ini tampak jelas pada penilaian volume seroma pada hari pertama dan total akumulasi selama 5 hari observasi drainase seroma. Hasil analisis statistik dengan menggunakan uji-t tidak berpasangan pada derajat kepercayaan 95\%, menunjukkan bahwa perbedaan rata-rata volume drainase seroma antara kedua kelompok tersebut tidak signifikan $(\mathrm{p}=0,053)$.

\section{Pembahasan}

Pada penelitian sebelumnya yang telah dilakukan oleh Loo dan Chow, ${ }^{5}$ didapatkan data pasien yang berusia 45 tahun atau lebih, secara statistik memiliki kemungkinan yang lebih besar untuk mengalami seroma. Walaupun pada penelitian ini didapatkan rentang usia yang bervariasi pada kedua kelompok penelitian, berdasarkan hasil uji-t tidak berpasangan, pada kedua kelompok berdasarkan usia dan juga IMT, tidak didapatkan perbedaan usia rata-rata dan juga nilai IMT pada kedua kelompok $(\mathrm{p}>0,05)$. Hasil analisis statistik tersebut memperlihatkan tidak terdapat perbedaan usia rata-rata dan besar IMT yang dapat memengaruhi hasil penelitian.

Sortino dan $\mathrm{Cicciu}^{10}$ menunjukkan pemberian dosis tinggi glukokortikoid sebelum tindakan pembedahan (30 mg/kgBB metilprednisolon) menghambat IL-6 dan C-reactive protein (CRP) dan juga menghambat aktivasi sistem kaskade inflamasi setelah tindakan pembedahan. Pada penelitian lain, dinyatakan bahwa glukokortikoid menekan proses inflamasi dengan membentuk

Tabel 2 Distribusi Volume Drainase Seroma Rata-rata

\begin{tabular}{|c|c|c|c|c|}
\hline & \multirow[b]{2}{*}{ Variabel } & \multicolumn{3}{|c|}{ Uji Normalitas Data *) } \\
\hline & & $\begin{array}{c}\text { Kontrol (NaCl) } \\
(n=15)\end{array}$ & & $\begin{array}{c}\text { Metilprednisolon } \\
(\mathrm{n}=15)\end{array}$ \\
\hline \multirow[t]{2}{*}{ Hari 1} & $\mathrm{p}$ & 0,088 & & 0,047 \\
\hline & Distribusi data & & Normal & \\
\hline \multirow[t]{2}{*}{ Hari 2} & $\mathrm{p}$ & 0,165 & & 0,133 \\
\hline & Distribusi data & & Normal & \\
\hline \multirow[t]{2}{*}{ Hari 3} & $\mathrm{p}$ & 0,021 & & 0,019 \\
\hline & Distribusi data & & Tidak normal & \\
\hline \multirow[t]{2}{*}{ Hari 4} & $\mathrm{p}$ & 0,005 & & 0,021 \\
\hline & Distribusi data & & Tidak normal & \\
\hline \multirow[t]{2}{*}{ Hari 5} & $\mathrm{p}$ & $<0,005$ & & $<0,005$ \\
\hline & Distribusi data & & Tidak normal & \\
\hline \multirow[t]{2}{*}{ Total } & $\mathrm{p}$ & 0,961 & & 0,472 \\
\hline & Distribusi data & & Normal & \\
\hline
\end{tabular}

Keterangan: *Uji Shapiro-Wilk 
Tabel 3 Perbedaan Volume Drainase Seroma

\begin{tabular}{|c|c|c|c|}
\hline \multirow[b]{2}{*}{ Variabel } & \multicolumn{3}{|c|}{ Kelompok Stastistik } \\
\hline & $\begin{array}{c}\text { Placebo }(\mathrm{NaCl}) \\
(\mathrm{n}=15)\end{array}$ & $\begin{array}{c}\text { Metilprednisolon } \\
(\mathrm{n}=15)\end{array}$ & $\mathbf{p}$ \\
\hline \multicolumn{4}{|l|}{ Hari 1} \\
\hline Rata-rata (SB) & $158(56,97)$ & $104,67(85,01)$ & \\
\hline Median (rentang) & $150(70-300)$ & $100(20-300)$ & $0,053^{*}$ \\
\hline Total volume & 2.370 & 1.570 & \\
\hline \multicolumn{4}{|l|}{ Hari 2} \\
\hline Rata-rata (SB) & $93,67(44,89)$ & $99,33(66,14)$ & \\
\hline Median (rentang) & $100(20-180)$ & $100(10-200)$ & $0,786^{*}$ \\
\hline Total volume & 1.405 & 1.490 & \\
\hline \multicolumn{4}{|l|}{ Hari 3} \\
\hline Rata-rata (SB) & $54,33(29,992)$ & $52,33(38,49)$ & \\
\hline Median (rentang) & $50(5-100)$ & $50(0-100)$ & $0,778^{* *}$ \\
\hline Total volume & 815 & 785 & \\
\hline \multicolumn{4}{|l|}{ Hari 4} \\
\hline Rata-rata (SB) & $28(19,62)$ & $29,67(31,08)$ & \\
\hline Median (rentang) & $20(0-50)$ & $20(0-100)$ & $0,701 * *$ \\
\hline Total volume & 420 & 445 & \\
\hline \multicolumn{4}{|l|}{ Hari 5} \\
\hline Rata-rata (SB) & $6,33(10,43)$ & $2,33(5,62)$ & \\
\hline Median (rentang) & $5(0-30)$ & $2(0-20)$ & $0,323 * *$ \\
\hline Total volume & 95 & 35 & \\
\hline \multicolumn{4}{|l|}{ Total Volume } \\
\hline Rata-rata (SB) & $340,33(118,63)$ & $288,33(164,51)$ & \\
\hline Median (rentang) & $320(130-550)$ & $290(30-560)$ & $0,329 *$ \\
\hline Total volume & 5.105 & 4.325 & \\
\hline
\end{tabular}

Keterangan: *uji-t tidak berpasangan; **Uji Mann Whitney

phospholipase inhibitor lipocortin, yang bekerja menekan produksi asam arakidonat yang penting untuk pembentukan prostaglandin dan leukotrien. Hal ini akan menekan proses inflamasi melalui penghambatan permeabilitas kapiler, edema, migrasi sel leukosit, proliferasi kapiler, fibroblas, dan deposit kolagen.

Pada penelitian ini volume drainase seroma lebih sedikit pada hari pertama dan total volume drainase bila dibandingkan dengan kontrol, tetapi berdasarkan analisis statistik data ini tidak berbeda signifikan. Hasil penelitian ini sesuai dengan hasil penelitian yang dilakukan oleh Okholm dan Axelsson ${ }^{13}$ bahwa didapatkan hubungan volume drainase selama tiga hari pertama pascaoperasi dengan pembentukan seroma yang tidak berbeda bermakna, sehingga dapat disimpulkan produksi seroma tidaklah terbukti dapat ditekan dengan pemberian glukokortikoid intravena.

Hal ini mungkin disebabkan karena masih terdapat ruang mati aksila. Tindakan pemasangan drain vakum hanya bersifat sementara sehingga ruang mati di aksila tetap ada. Penelitian yang dilakukan oleh Taghizadeh dkk. ${ }^{12}$ dikemukakan bahwa pemberian dengan $80 \mathrm{mg}$ triamsinolon dosis tunggal pada pasien seroma setelah operasi rekonstruksi payudara menurunkan pembentukan seroma secara signifikan. Pada penelitian di atas, rekonstruksi dilakukan dengan menggunakan flap latisimus dorsi, sehingga ruang mati aksila tertutup secara definitif. Berdasarkan penelitian yang dilakukan oleh Taghizadeh dkk., ${ }^{11}$ mungkin dapat dilakukan penelitian lebih lanjut profilaksis pembentukan seroma dengan menggabungkan 
antiinflamasi dan reduksi ruang mati aksila yang terbentuk pascaoperasi payudara.

Pada penelitian ini tidak ditemukan perbedaan infeksi dan gangguan penyembuhan luka, antara kedua kelompok penelitian, sebagai efek samping glukokortikoid, Keadaan ini menunjukkan bahwa penggunaan dosis tunggal steroid jangka pendek sebagai antiinflamasi tidak menimbulkan efek samping yang bermakna.

Penelitian ini mempunyai kekurangan, yaitu terdapat perbedaan antara jenjang usia yang jelas pada kedua kelompok, meskipun hasil analisis homogenitas usia dan IMT pada kedua kelompok sama. Penelitian ini belum dapat menyingkirkan faktor kemoterapi preoperatif yang mungkin dapat memengaruhi hasil penelitian ini.

Simpulan, pemberian metilprednisolon tidak efektif menurunkan volume drainase dari seroma pascaoperasi mastektomi.

\section{Daftar Pustaka}

1. Hashemi E, Kaviani A, Najafi M, Ebrahimi M, Hooshmand H, Montazeri A. Seroma formation after surgery for breast cancer. World J Surg Oncol. 2004;2:44.

2. Stanczyk M, Grala B, Zwierowicz T, Maruszynski M. Surgical resection for persistent seroma, following modified radical mastectomy. World J Surg Oncol. 2007;5:104.

3. Karakaya M, Karaman N, Özazlan C, Kurukahvecioğlu O, Bircan HY, Altinok M. Wound complications following breast cancer surgery. J Breast Health. 2006;2:85-8.

4. Junior NO. Hubungan antara seroma dengan body mass index dan kadar lekosit cairan seroma [disertasi]. Bandung: Universitas
Padjadjaran; 2010.

5. Loo WT, Chow LW. Factors predicting seroma formation after mastectomy for Chinese breast cancer patients. Indian J Cancer. 2007;44(3):99-103.

6. Kuroi K, Shimozuma K, Taguchi T, Imai $\mathrm{H}$, Yamashiro $\mathrm{H}$, Ohsumi $\mathrm{S}$, dkk. Pathophysiology of seroma in breast cancer. Breast Cancer J. 2005;12(4):288-93.

7. Soomro SA, Husain N, Shaikh BA, Maher $M$. Predicting factors of seroma formation after breast cancer surgery. Pak J Surg. 2006;22(4):201-4.

8. Setiawan J, Abdurahman M. Seroma dan radikalitas operasi mastektomi. PIT IKABI 2013. The $19^{\text {th }}$ Annual Scientific Meeting of IKABI; 23 Agustus 2013; Semarang, Indonesia; 2013.

9. Szecsi PB, Larsen J, Hørby J, Axelsson CK. Seroma production after breast cancer surgery has a pro-inflammatory component. Open Breast Cancer J. 2012;4:11-7.

10. Sortino F, Cicciu M. Strategies used to inhibit postoperative swelling following removal of impacted lower third molar. Dent Res J. $2011 ; 8(4): 162-71$.

11. Taghizadeh R, Shoaib T, Hart AM, WeilerMithoff EM. Triamcinolone reduces seroma re-accumulation in the extended latissimusdorsi donor site. J Plast Reconstr Aesthet Surg. 2008;61(6):636-42.

12. Tahmasebi S, Amirian A, Talei A. Axillary dissection in 44 breast cancer patients without seroma formation. Middle East $\mathrm{J}$ Cancer. 2011;2(2):65-9.

13. Okholm M, Axelsson CK. No effect of steroids on seroma formation after mastectomy. Dan Med Bull. 2011;58(2):A4241. 